\title{
Paro cardiorrespiratorio en la embarazada y cesárea perimortem
}

\section{Maternal cardiac arrest and perimortem cesarean delivery}

\section{Juan P. Ghiringhelli† y Héctor J. Lacassie 2*}

${ }^{1}$ Cátedra de Anestesiología y Reanimación, Universidad de Valparaíso, Hospital Naval Almirante Nef, Viña del Mar; ${ }^{2}$ División de Anestesiología, Pontificia Universidad Católica de Chile, Santiago. Chile

\section{Resumen}

El paro cardiorrespiratorio (PCR) en la mujer embarazada es una situación infrecuente, grave y de manejo multidisciplinario. La reanimación cardiopulmonar requiere consideraciones y particularidades propias de la embarazada, centradas en la fisiología y la anatomía, teniendo especial consideración la compresión aortocava, la intubación-ventilación difícil, la presencia de estómago lleno y el hecho que hay dos vidas involucradas. Las principales causas de PCR son las hemorrágicas, seguidas de las embólicas, cardiovasculares, anestésicas e infecciosas. Las principales acciones incluyen activación del código azul obstétrico con respuesta rápida para una eventual realización de histerotomía de emergencia oportuna en el mismo sitio evitando el traslado al quirófano, compresiones torácicas de buena calidad, desviación manual uterina a la izquierda, intubación endotraqueal y manejo avanzado de la vía aérea, todo esto con el fin de mejorar la sobrevida materno-fetal. La cesárea perimortem es un pilar en el manejo, favoreciendo el desenlace materno y eventualmente el fetal. Se debe realizar a los 4 minutos de una reanimación cardiopulmonar no exitosa. Sin embargo, aún hay retardo a la hora de indicarla, por lo que se debe incentivar el entrenamiento, la simulación en resucitación cardiopulmonar materna y las guías clínicas para todo el personal involucrado en la atención de pacientes obstétricas.

Palabras clave: Resucitación cardiopulmonar. Embarazo. Paro cardiaco. Cesárea perimortem.

\section{Abstract}

Cardiopulmonary arrest is a rare event during pregnancy and labor. It involves many subspecialties and allied health providers. Besides it requires knowledge of maternal physiology as it relates to resuscitation, particularly aortocaval compression, difficult airway, full stomach and the fact that there are two lives involved. The most frequent causes of cardiac arrest during pregnancy include bleeding, followed by embolism, infection, anesthesia complications and heart failure. The main steps required are: obstetric code activation with appropriate response for performing timely emergent hysterotomy in the same place avoiding the transfer to operating room; good-quality chest compressions; manual uterine displacement to the left, advanced pharmacological and airway management; and optimal care after resuscitation to improve maternal and fetal outcomes. Although current recommendations for maternal resuscitation include the performance of perimortem cesarean section after four minutes of unsuccessful cardiopulmonary resuscitation, deficits in knowledge about this procedure are common. Therefore, training and available evidence-based guidelines should be put in place for all obstetric caregivers.

Key words: Cardiopulmonary resuscitation. Pregnancy. Cardiac arrest. Perimortem cesarean.

Correspondencia:

*Héctor J. Lacassie

E-mail: lacassie@med.puc.cl
Disponible en internet: 27-10-2021 Rev Chil Obstet Ginecol. 2021;86(4):410-424

www.rechog.com CC BY-NC-ND (https://creativecommons.org/licenses/by-nc-nd/4.0/). 


\section{Introducción}

Se define como paro cardiorrespiratorio (PCR) al fenómeno fisiopatológico que se caracteriza por la incapacidad del corazón para mantener un nivel mínimo de flujo sanguíneo en el sistema circulatorio.

En las últimas décadas, el aumento de la edad materna, los embarazos de alto riesgo por el mayor uso de métodos de fertilización asistida y la comorbilidad, principalmente las enfermedades cardiacas y la obesidad, han aumentado el riesgo de presentar un PCR durante el embarazo, pasando de una incidencia previamente descrita de 1/30,000 a la actual de $1 / 12,000$ embarazos $^{1-3}$.

La mortalidad materna se define como la muerte durante el embarazo hasta los 42 días posparto. Esta definición incluye muertes por aborto o embarazo ectópico, pero excluye las causas incidentales ${ }^{4}$. Diariamente ocurren en todo el mundo 800 muertes maternas, la mayoría en países de bajos ingresos ${ }^{5}$. Así, mientras las cifras del Reino Unido sirven de ejemplo, con 7 muertes por cada 100,000 nacidos vivos, la realidad de los Estados Unidos de América es dispar y ha aumentado de 7.2 en 1989 a 17.8 por 100.000 nacidos vivos en los últimos años ${ }^{6}$. Chile tiene cifras cercanas a 13 por 100,000 nacidos vivos, una de las mejores de América Latina? ${ }^{7}$. Sin embargo, estuvo muy lejos del quinto objetivo de desarrollo del milenio, que proponía reducir la mortalidad materna a 9,98. El envejecimiento de las mujeres en edad fértil y la postergación de la maternidad determinan que las enfermedades concurrentes sean en la actualidad la causa más importante de muerte materna en Chile, explicando la dificultad para lograr los objetivos de la Organización de las Naciones Unidas (ONU) ${ }^{9}$.

La mortalidad materna es solo una pequeña representación de los eventos críticos maternos. Los cuasieventos (near misses) también deben ser considerados, aludiendo a mujeres que estuvieron cerca de morir durante el embarazo, el parto y el posparto hasta los 42 días. Ahí, su incidencia es muchísimo más alta, cercana a 1:141 embarazos ${ }^{10}$.

Por otra parte, la mortalidad perinatal incluye las muertes fetales tardías (definidas como la muerte previa al parto a partir de las 22 semanas de gestación) más las muertes neonatales precoces (definidas como las defunciones de recién nacidos producidas en los primeros 7 días de vida extrauterina). Se expresa por cada 1000 nacidos vivos y es un indicador universal de condiciones de vida y de calidad y acceso a los servicios de salud ${ }^{11}$.
El PCR materno es una situación compleja por el hecho de estar tratando dos pacientes y dos desenlaces mortales: neonatal y materno. La mayoría de los reportes corresponden a series de casos internacionales ${ }^{1,12}$. No obstante, en América Latina y en Chile no disponemos de mayores estudios, por lo que no conocemos su real incidencia ni la sobrevida.

La reanimación está centrada en la fisiología y la anatomía de la embarazada, siendo fundamental entender estos cambios que marcan diferencias en la realización y la eficacia de las maniobras de reanimación cardiopulmonar (RCP).

Nuestro objetivo es realizar una revisión sistemática del PCR en el ámbito obstétrico con énfasis en las particularidades de la RCP en el embarazo, para otorgar información actualizada que permita intervenciones protocolizadas y oportunas.

\section{Método}

El estudio se basó en dos preguntas clínicas: ¿cómo reanimar a una embarazada en PCR? y ¿cuál es el papel actual de la cesárea perimortem en la RCP materna?

Se hizo una búsqueda en las bases de datos PubMed (Medline), Google Scholar, SciELO y Embase utilizando los términos "Cardiopulmonary resuscitation", "Pregnancy", "Perimortem cesarean", "Maternal cardiac arrest" y "Cardiac arrest in pregnancy". Los idiomas de la búsqueda se restringieron al inglés y el español. Además, se buscó en las referencias de los artículos seleccionados y en la literatura gris. Mediante esta búsqueda estructurada se obtuvieron 84 artículos. Luego de su análisis fueron excluidos aquellos que no presentaban información relevante, los duplicados, los que no tenían el texto completo disponible y los publicados hace más de 20 años. Finalmente quedaron 50 artículos con información relevante para el desarrollo de la presente revisión, incluyendo reportes de la ONU y de cifras estadísticas.

\section{Repercusiones de los cambios fisiológicos del embarazo en la reanimación cardiopulmonar}

Los sistemas en que se producen los mayores cambios son el hemodinámico y el respiratorio, con un aumento del gasto cardiaco del $30-50 \%$, mayor consumo de oxígeno e incremento de la ventilación por minuto. Cerca de un tercio del gasto cardiaco va destinado al flujo placentario, en comparación con el 1-2\% 
del útero no gestante. El resto de las modificaciones circulatorias se resumen en la tabla 1. También existen modificaciones respiratorias y de la vía aérea, renales, metabólicas, de la coagulación y del sistema nervioso central, que tendrán distintas repercusiones en la RCP (Tabla 2).

El síndrome de compresión aortocava (Fig. 1) ocurre a partir de las 20 semanas de gestación 0 antes en determinados casos, como embarazos múltiples, macrosomía, polihidramnios y obesidad materna ${ }^{6}$. Se produce cuando la gestante se encuentra en decúbito supino y es secundario a la compresión de la aorta y la vena cava inferior, a nivel intraabdominal por el útero, lo que desencadena una situación de bajo gasto (reducción del volumen sistólico y del gasto cardiaco) por disminución del retorno venoso. La clínica que se presenta consiste en la tríada de bradicardia, hipotensión arterial y síncope en decúbito supino.

Esto puede prevenirse o resolverse colocando a la gestante en decúbito lateral izquierdo o desplazando el útero a lateral. En un estudio mediante resonancia magnética se observó que el decúbito lateral izquierdo mejora la hemodinamia materna, con un incremento del $27 \%$ y del $35 \%$ del volumen sistólico en gestaciones de 20 y 32 semanas, respectivamente ${ }^{13}$.

Las modificaciones de la vía aérea van a determinar que la embarazada sea considerada como vía aérea difícil tanto para la ventilación como para la intubación traqueal. Los cambios gastrointestinales determinan un mayor riesgo de broncoaspiración de contenido gástrico. Por otra parte, las compresiones torácicas pueden ser difíciles de realizar por el diafragma elevado, las costillas ensanchadas y las mamas hipertrofiadas.

\section{Sobrevida del paro cardiorrespiratorio en la embarazada}

La sobrevida del PCR materno intrahospitalario fluctúa entre el $30 \%$ y el $70 \%$ según los últimos reportes internacionales ${ }^{1,3,12,14}$, siendo ahora mayor que en los reportes iniciales ${ }^{15,16}$. Uno de los que tuvo mayor seguimiento fue el reporte de la National Impatient Sample de 1998 a 2011, que mostró que la supervivencia se elevaba al $58.9 \%$, por encima incluso de la sobrevida del PCR hospitalario en población no embarazada $(21 \%)^{17,18}$. Esto se podría deber a que la población embarazada es mayoritariamente joven, con controles prenatales, o a la inclusión de PCR en el posparto, asociados a mejor pronóstico'.
Tabla 1. Resumen de los cambios hemodinámicos en la embarazada

\begin{tabular}{ll}
\hline Parámetro & Cambio \\
\hline Gasto cardiaco & Aumenta $40-50 \%$ \\
Volumen sistólico & Aumenta 20-30\% \\
$\begin{array}{l}\text { Volumen final diastólico ventrículo } \\
\text { izquierdo }\end{array}$ & Aumenta \\
\hline $\begin{array}{l}\text { Volumen sistólico final ventrículo } \\
\text { izquierdo }\end{array}$ & No cambia \\
\hline Presión sistólica & Disminuye 5-10 \\
\hline Presión diastólica & mmHg \\
\hline Presión venosa central & Disminuye $10-20$ \\
Presión capilar pulmonar & mmHg \\
\hline Resistencia vascular sistémica & No cambia \\
\hline Resistencia vascular pulmonar & No cambia \\
\hline Frecuencia cardiaca & Disminuye $15-20 \%$ \\
Contractibilidad & Disminuye $30 \%$ \\
Volemia & Aumenta $15-25 \%$ \\
\hline
\end{tabular}

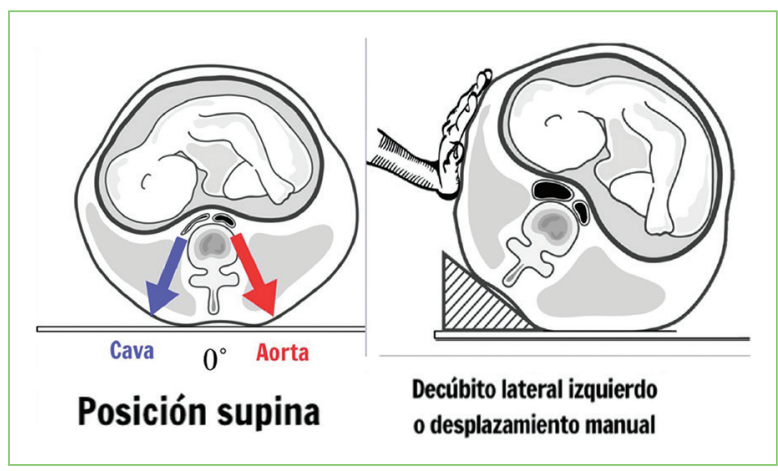

Figura 1. Síndrome de compresión aortocava en supino y prevención de su ocurrencia en decúbito lateral izquierdo o mediante desplazamiento manual del útero.

\section{Causas de paro cardiorrespiratorio en la embarazada}

La gestante puede sufrir un PCR por las mismas causas que cualquier mujer del mismo grupo de edad, a las que se añadirían las causas relacionadas con el embarazo. Esta clasificación se expone en la tabla 3.

La hemorragia, la preeclampsia y las complicaciones tromboembólicas han sido históricamente las causas 
Tabla 2. Cambios fisiológicos de la embarazada y su repercusión en la reanimación

\begin{tabular}{|c|c|c|c|c|c|c|c|}
\hline Sistema & Cambio fisiológico & $\begin{array}{l}\text { Repercusión en la } \\
\text { RCP }\end{array}$ & Sistema & \multicolumn{2}{|c|}{ Cambio fisiológico } & $\begin{array}{l}\text { Repercusión en la } \\
\text { RCP }\end{array}$ & テָ \\
\hline \multirow[t]{9}{*}{ Cardiovascular } & $\begin{array}{l}\text { Aumento gasto } \\
\text { cardiaco }\end{array}$ & $\begin{array}{l}\text { Aumento } \\
\text { requerimientos } \\
\text { anestésicos }\end{array}$ & & \multicolumn{2}{|c|}{$\begin{array}{l}\text { Aumenta filtrado } \\
\text { glomerular }\end{array}$} & $\begin{array}{l}\text { Modificación de la } \\
\text { eliminación de } \\
\text { fármacos }\end{array}$ & 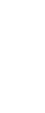 \\
\hline & \multirow[t]{2}{*}{$\begin{array}{l}\text { Aumento volumen } \\
\text { plasmático }\end{array}$} & \multirow{2}{*}{$\begin{array}{l}\text { Anemia dilucional, } \\
\text { disminución } \\
\text { capacidad } \\
\text { transporte de } \\
\text { oxígeno }\end{array}$} & \multirow[t]{3}{*}{ Gastrointestinal } & \multicolumn{2}{|c|}{ Motilidad disminuida } & $\begin{array}{l}\text { Aumenta riesgo } \\
\text { aspiración }\end{array}$ & (2) \\
\hline & & & & \multicolumn{2}{|c|}{$\begin{array}{l}\text { Disminución presión } \\
\text { esfínter esofágico } \\
\text { inferior }\end{array}$} & $\begin{array}{l}\text { Aumenta riesgo } \\
\text { aspiración, } \\
\text { considerar como }\end{array}$ & $\frac{\check{c}}{.0}$ \\
\hline & \multirow{2}{*}{$\begin{array}{l}\text { Presión } \\
\text { coloidosmótica } \\
\text { disminuye }\end{array}$} & \multirow[t]{2}{*}{$\begin{array}{l}\text { Mayor riesgo de } \\
\text { edema pulmonar }\end{array}$} & & & & $\begin{array}{l}\text { paciente con } \\
\text { estómago lleno }\end{array}$ & 을 \\
\hline & & & \multirow[t]{5}{*}{ Otros } & \multirow{2}{*}{\multicolumn{2}{|c|}{$\begin{array}{l}\text { Mamas } \\
\text { hipertrofiadas }\end{array}$}} & Compresiones más & $\ddot{\tilde{\omega}}$ \\
\hline & $\begin{array}{l}\text { Resistencia vascular } \\
\text { sistémica disminuye }\end{array}$ & $\begin{array}{l}\text { Retraso aparición } \\
\text { signos de } \\
\text { hipovolemia }\end{array}$ & & & & $\begin{array}{l}\text { dificultosas } \\
\text { Usar laringoscopio } \\
\text { mango corto }\end{array}$ & $\begin{array}{l}\frac{1}{0} \\
\frac{1}{ \pm} \\
\frac{ \pm}{0}\end{array}$ \\
\hline & $\begin{array}{l}\text { Compresión } \\
\text { aortocava a partir } \\
\text { semana } 20 \text { en }\end{array}$ & $\begin{array}{l}\text { Necesidad de } \\
\text { desplazar el útero a } \\
\text { la izquierda durante }\end{array}$ & & \multicolumn{2}{|c|}{$\begin{array}{l}\text { Aumenta flujo } \\
\text { sanguíneo útero }\end{array}$} & $\begin{array}{l}\text { Potencial causa de } \\
\text { hemorragia masiva } \\
\text { de rápido desarrollo }\end{array}$ & 宸 \\
\hline & gestaciones únicas & $\begin{array}{l}\text { la RCP } \\
\text { Disminución reserva } \\
\text { circulatoria } \\
\text { Vías venosas sobre }\end{array}$ & & \multicolumn{2}{|c|}{$\begin{array}{l}\text { Tamaño uterino } \\
\text { aumentado }\end{array}$} & $\begin{array}{l}\text { Incremento riesgo } \\
\text { síndrome } \\
\text { compresión } \\
\text { aortocava }\end{array}$ & 힌 \\
\hline & & diafragma & & \multirow{3}{*}{\multicolumn{2}{|c|}{$\begin{array}{l}\text { Disminución espacio } \\
\text { raquídeo }\end{array}$}} & Hipotensión & 4 \\
\hline \multirow[t]{5}{*}{ Vía aérea } & $\begin{array}{l}\text { Ingurgitación vía } \\
\text { aérea superior }\end{array}$ & $\begin{array}{l}\text { Tubos orotraqueales } \\
\text { más pequeños }\end{array}$ & & & & $\begin{array}{l}\text { marcada si mismas } \\
\text { dosis que en }\end{array}$ & 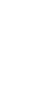 \\
\hline & Mayor riesgo de & Evitar vía nasal & & & & gestante & 응 \\
\hline & & & & \multirow{2}{*}{\multicolumn{2}{|c|}{$\begin{array}{l}\text { Dependencia } \\
\text { simpática en } \\
\text { aumento }\end{array}$}} & Hipotensión & 은 \\
\hline & $\begin{array}{l}\text { Aumentan } \\
\text { Mallampati y } \\
\text { Cornack }\end{array}$ & $\begin{array}{l}\text { Vía aérea difícil, } \\
\text { aumenta el riesgo } \\
\text { de fracaso } 10 \text { veces }\end{array}$ & & & & $\begin{array}{l}\text { marcada si bloqueo } \\
\text { espinal alcanza } \\
\text { niveles superiores }\end{array}$ & $\frac{1}{0}$ \\
\hline & & $\begin{array}{l}\text { Intubación por el } \\
\text { más experto }\end{array}$ & & \multirow{2}{*}{\multicolumn{2}{|c|}{ Estado protrombótico }} & $\begin{array}{l}\text { Considerar causa } \\
\text { embólica del PCR }\end{array}$ & $\stackrel{ \pm}{ \pm}$ \\
\hline \multirow[t]{8}{*}{ Respiratorio } & \multirow{2}{*}{$\begin{array}{l}\text { Aumenta volumen } \\
\text { minuto }\end{array}$} & \multirow{2}{*}{$\begin{array}{l}\text { Alcalosis } \\
\text { respiratoria }\end{array}$} & & & & Tromboprofilaxis & 엉 \\
\hline & & & \multirow{2}{*}{\multicolumn{4}{|c|}{$\begin{array}{l}\text { CRF: capacidad residual funcional; RCP: reanimación cardiopulmonar; } \\
\mathrm{PaO}_{2} \text { : presión arterial de oxígeno; PCR: paro cardiorrespiratorio; } \mathrm{V} / \mathrm{Q} \text { : relación } \\
\text { ventilación/perfusión pulmonar. }\end{array}$}} & $\frac{\bar{c}}{0}$ \\
\hline & $\begin{array}{l}\text { Aumenta consumo } \\
\text { de oxígeno }\end{array}$ & $\begin{array}{l}\text { Aparición de hipoxia } \\
\text { con mayor rapidez. } \\
\text { Daño cerebral } \\
\text { hipóxico más rápido } \\
\text { que en paciente no } \\
\text { embarazada }\end{array}$ & & & & & 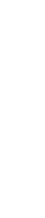 \\
\hline & \multirow[t]{2}{*}{ Disminución CRF } & \multirow{2}{*}{$\begin{array}{l}\text { Disminución } \mathrm{PaO2} \\
\text { rápidamente con la } \\
\text { apnea }\end{array}$} & \multicolumn{2}{|c|}{ Causas obstétricas } & \multicolumn{2}{|c|}{ Causas no obstétricas } & + \\
\hline & & & \multicolumn{2}{|c|}{$\begin{array}{l}\text { Hemorragia posparto } \\
(28 \%)\end{array}$} & \multicolumn{2}{|c|}{ Enfermedad cardiovascular $(13 \%)$} & 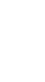 \\
\hline & $\begin{array}{l}\text { Aumenta shunt } \\
\text { fisiológico }\end{array}$ & $\begin{array}{l}\text { Intolerancia a las } \\
\text { alteraciones } \mathrm{V} / 0\end{array}$ & \multicolumn{2}{|c|}{$\begin{array}{l}\text { Hemorragia anteparto } \\
(16.5 \%)\end{array}$} & \multicolumn{2}{|c|}{$\begin{array}{l}\text { Complicaciones anestésicas } \\
(7-15 \%)\end{array}$} & $\begin{array}{l}\frac{c}{\omega} \\
\stackrel{n}{\check{c}} \\
\stackrel{0}{0}\end{array}$ \\
\hline & \multirow[t]{2}{*}{$\begin{array}{l}\text { Elevación de } \\
\text { diafragma }\end{array}$} & \multirow{2}{*}{$\begin{array}{l}\text { Drenaje pleural más } \\
\text { a cefálico } \\
\text { Compresiones } \\
\text { torácicas más } \\
\text { dificultosas }\end{array}$} & \multicolumn{2}{|c|}{$\begin{array}{l}\text { Embolia de líquido } \\
\text { amniótico }(11 \%)\end{array}$} & Sepsis $(5-10$ & & 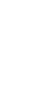 \\
\hline & & & $\begin{array}{l}\text { Síndromes hiper } \\
\text { - eclampsia }(5 \%)\end{array}$ & nsivos & Tromboembo & a pulmonar $(6 \%)$ & 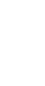 \\
\hline Renal & Alcalosis respiratoria & $\begin{array}{l}\text { Incremento en los } \\
\text { requerimientos }\end{array}$ & Síndrome HELLP & $(0.1 \%)$ & Trauma $(2 \%)$ & & $i \bar{n}$ \\
\hline & & ventilatorios & Cardiopatía peri & & Toxicidad 10 & $5 \%)$ & \\
\hline
\end{tabular}

Tabla 2. Cambios fisiológicos de la embarazada y su

repercusión en la reanimación (Continuación) 
más frecuentes de $\mathrm{PCR}^{3,6}$. Un reporte de Mhyre, et al. confirma que la hemorragia (tanto anteparto como posparto) es la principal causa de PCR materno. Dentro de las causas que presentan mejor supervivencia se encuentran las complicaciones derivadas de la anestesia, el shock anafiláctico y la toxicidad por sulfato de magnesio ${ }^{12,19}$, mientras que las de peor pronóstico son la hemorragia antenatal, el infarto al miocardio, la embolia amniótica, la disección aórtica y el trauma ${ }^{1,12}$.

Existe otra clasificación más útil, con ventajas importantes por señalar la etiología sumado a un componente nemotécnico (ABCDEFGH), que a continuación se describe y que se resume en la tabla 4:

A. Anestesia (complicaciones): en un estudio realizado en el Reino Unido ${ }^{12}$ fue la principal causa de PCR en gestantes. El reporte de Mhyre, et al. ${ }^{1}$ solo la cita con un $8 \%$, recalcando que la sobrevida fue cercana al $82 \%$.

B. Hemorragia (bleeding): es la causa más frecuente de PCR materno, destacando los trastornos del espectro de la placenta acreta $^{20}$, el desprendimiento prematuro de placenta y la atonía uterina.

C. Cardiovascular: es la principal causa de mortalidad materna en los países desarrollados ${ }^{6}$. Debe tenerse en cuenta que el embarazo aumenta cuatro veces el riesgo de tener un infarto al miocardio, y si a esto se suma una edad materna mayor de 40 años el riesgo es 30 veces más alto que en las gestantes menores de 20 años ${ }^{21}$.

D. Drogas (fármacos):

- La oxitocina es un potente vasodilatador que presenta, además, efecto inotrópico negativo, lo que puede traducirse en hipotensión arterial, taquicardia e isquemia miocárdica, pudiendo desencadenar un PCR por infusiones a gran velocidad o en bolo.

- El sulfato de magnesio se usa para la neuroprotección fetal en casos de partos pretérmino y para la profilaxis de la eclampsia. Entre sus efectos se encuentran la vasodilatación, la depresión del sistema nervioso central, la interacción con drogas anestésicas y su potencial toxicidad. Su antídoto es el gluconato o cloruro de calcio.

E. Embolias:

- Embolia de líquido amniótico: es el diagnóstico que con más frecuencia derivó en PCR. Es muy subdiagnosticada por tener una clínica muy inespecífica (cianosis, hipotensión arterial, hemorragia), ocurre en 1:80,000 embarazos, en relación con el parto o alumbramiento, y se asocia a un $60-80 \%$ de mortalidad ${ }^{1}$.
Tabla 4. Regla nemotécnica para las principales causas de paro cardiorrespiratorio en la embarazada 6,20

\begin{tabular}{|c|c|c|}
\hline Letra & Causa & Causa específica \\
\hline \multirow[t]{6}{*}{ A } & \multirow[t]{6}{*}{ Anestesia } & Hipotensión arterial \\
\hline & & $\begin{array}{l}\text { Intoxicación sistémica por } \\
\text { anestésicos locales }\end{array}$ \\
\hline & & Bloqueo neuroaxial alto \\
\hline & & $\begin{array}{l}\text { Imposibilidad intubación } \\
\text { endotraqueal (pérdida vía aérea) }\end{array}$ \\
\hline & & Neumonía por aspiración \\
\hline & & Depresión respiratoria \\
\hline \multirow[t]{10}{*}{ B } & \multirow{10}{*}{$\begin{array}{l}\text { Sangrado } \\
\text { (bleeding) }\end{array}$} & Inercia uterina \\
\hline & & Espectro de la placenta acreta \\
\hline & & $\begin{array}{l}\text { Desprendimiento placenta } \\
\text { normoinserta }\end{array}$ \\
\hline & & Rotura uterina \\
\hline & & Coagulopatía \\
\hline & & Inversión uterina \\
\hline & & Lesión del canal de parto \\
\hline & & Restos ovulares \\
\hline & & Sangrado posquirúrgico \\
\hline & & Reacción transfusional \\
\hline \multirow[t]{8}{*}{ C } & \multirow[t]{8}{*}{ Cardiovascular } & Infarto al miocardio \\
\hline & & Cardiomiopatía periparto \\
\hline & & Valvulopatías \\
\hline & & Arritmias \\
\hline & & Cardiopatías congénitas \\
\hline & & Edema pulmonar \\
\hline & & Disección aórtica \\
\hline & & Endocarditis infecciosa \\
\hline \multirow[t]{6}{*}{$\mathrm{D}$} & \multirow{6}{*}{$\begin{array}{l}\text { Drogas } \\
\text { (fármacos) }\end{array}$} & Oxitocina \\
\hline & & Sulfato de magnesio \\
\hline & & Error de medicación (tipo o dosis) \\
\hline & & Drogas ilícitas \\
\hline & & Anafilaxia \\
\hline & & Opiáceos \\
\hline \multirow[t]{3}{*}{$E$} & \multirow[t]{3}{*}{ Embolia } & Embolia líquido amniótico \\
\hline & & Embolia pulmonar \\
\hline & & Embolia aérea \\
\hline
\end{tabular}

Accidentes cerebrovasculares 
Tabla 4. Regla nemotécnica para las principales causas de paro cardiorrespiratorio en la embarazada ${ }^{6,20}$ (Continuación)

\begin{tabular}{|c|c|c|}
\hline Letra & Causa & Causa específica \\
\hline \multirow[t]{2}{*}{$\mathrm{F}$} & \multirow[t]{2}{*}{ Fiebre } & Sepsis \\
\hline & & Infección \\
\hline \multirow[t]{2}{*}{ G } & \multirow[t]{2}{*}{$\begin{array}{l}\text { Generales } \\
\text { (no } \\
\text { obstétricas) }\end{array}$} & $\begin{array}{l}\text { 6H: hipoxia, hidrogeniones, hipo/ } \\
\text { hiperpotasemia, hipovolemia, } \\
\text { hipotermia, hipoglucemia }\end{array}$ \\
\hline & & $\begin{array}{l}\text { 6T: trombosis coronaria, trombosis } \\
\text { pulmonar, tóxicos, neumotórax a } \\
\text { tensión, taponamiento cardiaco, } \\
\text { trauma }\end{array}$ \\
\hline \multirow[t]{4}{*}{ H } & \multirow[t]{4}{*}{ Hipertensión } & Preeclampsia \\
\hline & & Eclampsia \\
\hline & & Síndrome HELLP \\
\hline & & Hemorragia intracerebral \\
\hline
\end{tabular}

- Tromboembolia pulmonar: constituye una de las mayores causas de mortalidad materna prevenible. Su incidencia ha disminuido gracias a la implementación de protocolos de tromboprofilaxis ${ }^{22}$.

- Accidente cerebrovascular: debido al estado procoagulante aumenta el riesgo de trombosis de las venas cerebrales y del seno venoso, y ocurre con más frecuencia en el tercer trimestre y las primeras 4 semanas posparto. Sus factores de riesgo son la edad materna avanzada, las infecciones, la hipertensión arterial, la hiperemesis y la cesárea.

F. Fiebre (sepsis): el shock séptico se caracteriza por producir hipotensión arterial refractaria, hipoperfusión tisular y acidosis láctica, y se manifiesta con fiebre, taquicardia y disnea. Las causas son diversas y entre ellas destacan la presencia de estreptococos del grupo A en el tracto genital, la infección de herida operatoria y la corioamnionitis.

G. Los traumatismos son comunes y mortales en el embarazo, pudiendo estar asociados al $20-30 \%$ de las muertes maternas. No obstante, generalmente no son incluidas dentro de la mortalidad materna, subestimando su real importancia ${ }^{23,24}$.

H. Hipertensión arterial: la preeclampsia complica en torno a un $7 \%$ de las gestaciones e incrementa el riesgo de morbimortalidad materna y fetal ${ }^{6}$. La forma en que la preeclampsia puede desencadenar un PCR es variada, incluyendo hipoxia, falla hepática en el síndrome HELLP (hemolysis, elevated liver enzymes and low platelets), eclampsia y hemorragia cerebral. Esta última es la principal causa de muerte en las pacientes con preeclampsia.

\section{Principios de la reanimación en la embarazada}

Para tener más éxito en un ámbito donde no existe una formación sistemática, como el obstétrico, son necesarios una preparación y un entrenamiento permanente en RCP de los equipos implicados ${ }^{25}$. En principio se recomiendan al menos cuatro personas para la realización de maniobras de soporte vital básico (SVB) hasta la llegada del equipo de PCR materna (Fig. 2), que efectuará las maniobras de soporte vital avanzado (SVA). Por otra parte, el entrenamiento de la población en maniobras de SVB es fundamental, ya que muchas personas serán los primeros respondedores en un PCR extrahospitalario materno, que hasta el momento se asocia a una pobre sobrevida, en torno al $7-12 \%{ }^{26}$.

La reanimación debe ser liderada por un profesional que conozca las particularidades de la embarazada. El liderazgo debería dividirse entre la reanimación materna, que estaría a cargo del anestesiólogo o del equipo de RCP, la reanimación fetal, de la que se encargaría el neonatólogo, y la decisión eventual de cesárea perimortem, tomada por el ginecoobstetra.

El bienestar materno es el mejor predictor del bienestar fetal. La mejor maniobra de reanimación fetal es reanimar efectivamente a la madre, identificando y tratando precozmente las patologías asociadas, ya que se ha descrito que el $74 \%$ de las gestantes en PCR tenían enfermedades coexistentes ${ }^{1}$.

La prioridad es la realización de maniobras básicas de RCP que permitan la circulación materna a los órganos vitales, para evitar al máximo las secuelas por hipoxemia. En este contexto, el $84 \%$ de las pacientes obstétricas hospitalizadas que desarrollaron PCR presentaban signos de deterioro en las 8 horas previas ${ }^{17}$. De esta manera, es primordial el manejo preventivo de las afecciones que conducen al PCR, como la preeclampsia o la sepsis.

Existen acciones propias de la reanimación de la embarazada que resultan fundamentales para el éxito del binomio materno-fetal ${ }^{6}$ :

- Establecer un acceso venoso supradiafragmático para una repleción rápida del volumen intravascular y la administración de fármacos. Un acceso inferior probablemente impida la llegada de los fármacos al corazón materno, debido a la compresión de la vena cava por el útero grávido. 


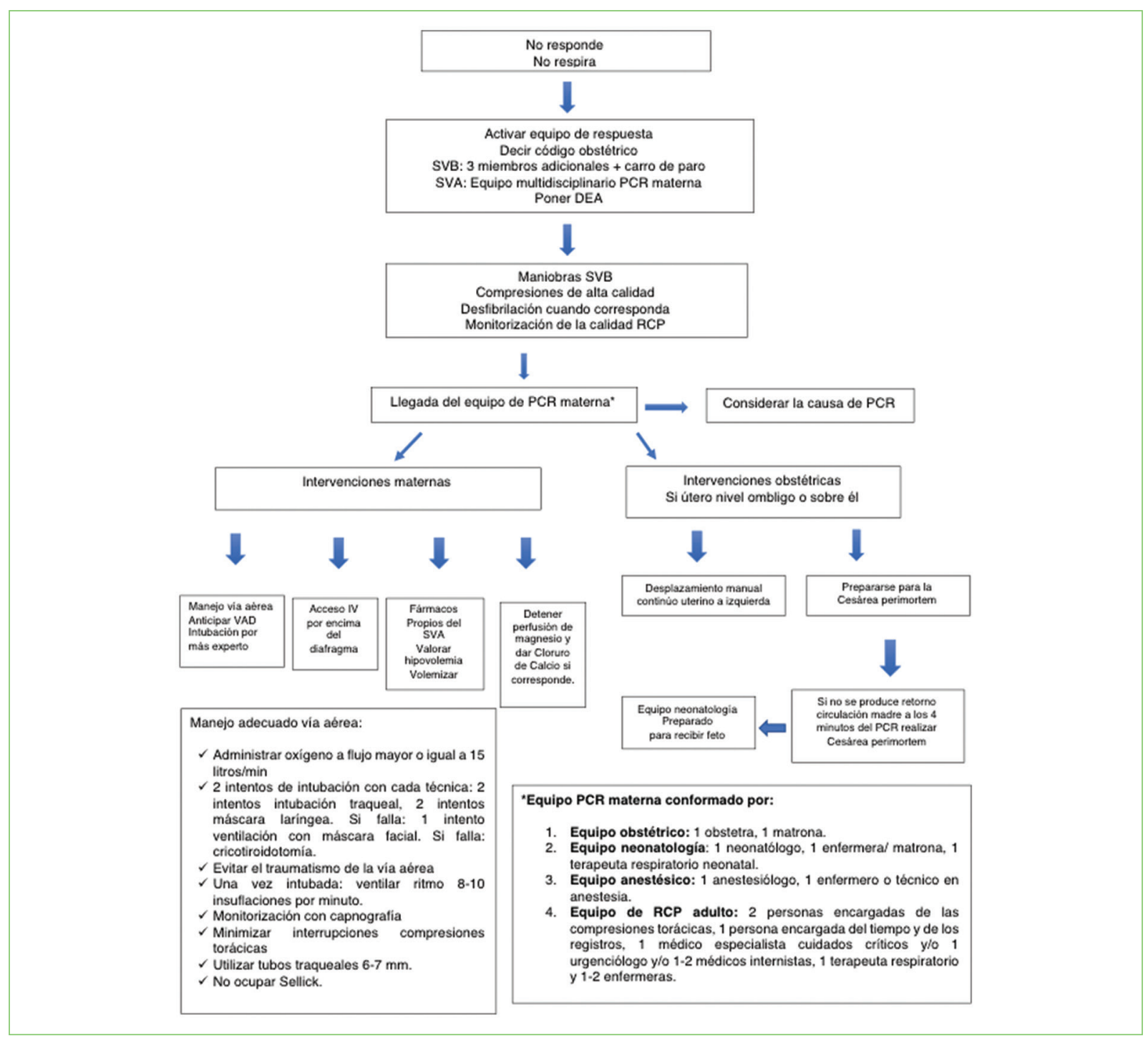

Figura 2. Algoritmo de reanimación cardiopulmonar (RCP) en la embarazada. DEA: desfibrilador externo automático; PCR: paro cardiorrespiratorio; SVA: soporte vital avanzado; SVB: soporte vital básico.

- Desplazar manualmente el útero a la izquierda.

- Manejo avanzado de la vía aérea por un anestesiólogo o experto.

- Estar preparados para una cesárea perimortem si no se recupera la circulación espontánea a los 4 minutos del PCR.

Las acciones son simultáneas, no secuenciales.

\section{Enfrentamiento de atención del paro cardiorrespiratorio. Algoritmos de actuación}

La American Heart Association (AHA) recomienda guiarse por el concepto de la "cadena de superviven- que desarrolladas de forma secuencial y correcta se traducen en una mayor tasa de supervivencia y un mejor pronóstico neurológico. Los eslabones de esta cadena incluyen el reconocimiento del PCR, la activación del código de emergencia, el inicio rápido de la RCP, la desfibrilación precoz y los cuidados tras el $\mathrm{PCR}^{27}$.

Desde el año 2010, la AHA ha cambiado sus recomendaciones en la secuencia de reanimación, pasando del A-B-C (vía aérea [airway], ventilación [breathing] y circulación [circulation]) a C-A-B, haciendo énfasis en la circulación más que en la ventilación.

En el año 2020 se publicó el consenso internacional de las guías de SVA, en el que las recomendaciones para el PCR en la gestante no sufrieron cambios mayores desde la última revisión de 2015 (Tabla 5), 
Tabla 5. Recomendaciones de la American Heart Association para la reanimación cardiopulmonar de la embarazada, con su nivel y fuerza de recomendación ${ }^{6}$

\begin{tabular}{|c|c|c|c|}
\hline Letra & Nivel* & Clase $^{\dagger}$ & Recomendación de RCP \\
\hline \multirow[t]{9}{*}{ C } & C & $\begin{array}{l}\text { Clase } \\
\text { Ila }\end{array}$ & $\begin{array}{l}\text { Las compresiones torácicas deben realizarse de forma ininterrumpida, de alta calidad, con una } \\
\text { profundidad de } 5 \mathrm{~cm} \text {, con una frecuencia de al menos } 100 \text { por minuto y una relación } \\
\text { compresión-ventilación de } 30: 2 \text { y permitiendo la reexpansión torácica entre compresiones. }\end{array}$ \\
\hline & C & Clase I & Las compresiones deben realizarse con la paciente en posición supina. \\
\hline & C & Clase Ila & $\begin{array}{l}\text { Las interrupciones de las compresiones deben minimizarse y limitarse a } 10 \text { segundos, con excepción } \\
\text { de intervenciones específicas como el uso de dispositivos de vía aérea avanzada y desfibrilador. }\end{array}$ \\
\hline & C & Clase Ila & $\begin{array}{l}\text { El reanimador debe poner la palma de su mano en el centro del pecho de la víctima y la base de la } \\
\text { otra encima de la primera mano, de modo que se superpongan y estén paralelas. }\end{array}$ \\
\hline & C & Clase I & $\begin{array}{l}\text { Se debe realizar el desplazamiento uterino izquierdo continuo a todas las embarazadas en PCR si el } \\
\text { útero está palpable a nivel o sobre el ombligo, para liberar la compresión aortocava. }\end{array}$ \\
\hline & C & Clase I & $\begin{array}{l}\text { Se debe instalar un acceso intravenoso sobre el diafragma, para asegurar que la administración de } \\
\text { medicación no se ve obstruida por el útero grávido. }\end{array}$ \\
\hline & C & Clase I & Se debe registrar el momento en que se confirma la ausencia de pulso. \\
\hline & C & Clase Ila & $\begin{array}{l}\text { Los fármacos y las dosis habituales son los mismos que se recomiendan durante el SVA en la } \\
\text { mujer no embarazada. }\end{array}$ \\
\hline & C & Clase IIb & $\begin{array}{l}\text { Se debe considerar la administración de } 1 \mathrm{mg} \text { de epinefrina intravenosa u oral cada 3-5 minutos. } \\
\text { En vista de los efectos uterotónicos que la vasopresina ejerce, y dado que es equivalente a la } \\
\text { epinefrina, esta última será de elección. }\end{array}$ \\
\hline \multirow[t]{11}{*}{ A } & C & Clase I & Notificación rápida ante un PCR en el embarazo para que el equipo de PCR materna acuda rápido. \\
\hline & C & Clase I & $\begin{array}{l}\text { La hipoxemia siempre debe ser considerada como una causa de PCR en el embarazo; por tanto, el } \\
\text { soporte ventilatorio precoz puede ser necesario. }\end{array}$ \\
\hline & C & Clase I & Se debe administrar oxígeno al $100 \%$ mediante mascarilla facial para tratar o prevenir la hipoxemia. \\
\hline & C & Clase I & La intubación endotraqueal debe ser realizada por un experto. \\
\hline & C & Clase I & Se recomienda insertar un tubo endotraqueal de $6-7 \mathrm{~mm}$ de diámetro. \\
\hline & C & Clase Ila & Idealmente no se deben realizar más de 2 intentos de laringoscopia. \\
\hline & C & Clase I & La estrategia de elección ante la intubación fallida serán los dispositivos supraglóticos. \\
\hline & C & Clase I & $\begin{array}{l}\text { Deben evitarse los intentos prolongados de intubación para prevenir la hipoxia, la interrupción de } \\
\text { las compresiones, el trauma y el sangrado de la vía aérea. }\end{array}$ \\
\hline & C & Clase III & No se recomienda la compresión cricoidea. \\
\hline & C & Clase I & $\begin{array}{l}\text { Se recomienda la capnografía continua, que junto con la valoración clínica es el método más } \\
\text { realista de monitorizar y comprobar la colocación correcta del tubo endotraqueal. }\end{array}$ \\
\hline & C & Clase Ila & $\begin{array}{l}\text { Los hallazgos relacionados con unas compresiones adecuadas y la recuperación de la circulación } \\
\text { espontánea incluyen el incremento del } \mathrm{CO}_{2} \text { exhalado o valores }>10 \mathrm{mmHg} \text {. }\end{array}$ \\
\hline \multirow[t]{2}{*}{ B } & C & Clase IIb & $\begin{array}{l}\text { Un miembro del equipo inicial de respuesta debe iniciar la ventilación con bolsa-mascarilla y } \\
\text { oxígeno al } 100 \% \text {, con un flujo en el reservorio a velocidad de al menos } 15 \mathrm{l} / \mathrm{min} \text {. }\end{array}$ \\
\hline & C & Clase Ila & La técnica de ventilación con dos manos es la preferida. \\
\hline \multirow[t]{6}{*}{ D } & C & Clase I & Se debe usar el mismo protocolo de desfibrilación que en la mujer no gestante. \\
\hline & C & Clase I & $\begin{array}{l}\text { La paciente deberá ser desfibrilada con una descarga de energía bifásica de } 120-200 \mathrm{~J} \text {, con } \\
\text { incrementos paulatinos de la energía de descarga si la primera no es efectiva y el dispositivo lo permite. }\end{array}$ \\
\hline & C & Clase Ila & Las compresiones se deben reanudar inmediatamente después de la administración del choque. \\
\hline & C & Clase IIb & $\begin{array}{l}\text { En las unidades hospitalarias en las que el personal no está entrenado en el reconocimiento de los } \\
\text { ritmos del electrocardiograma o donde es raro el uso del desfibrilador, como las unidades } \\
\text { obstétricas, debe considerarse el uso de un desfibrilador externo automático. }\end{array}$ \\
\hline & C & Clase Ila & $\begin{array}{l}\text { La colocación del parche/pala anterolateral se realiza de forma estándar. La pala/parche lateral } \\
\text { debe colocarse por debajo del tejido mamario (consideración importante en la gestante). }\end{array}$ \\
\hline & C & Clase Ila & Se recomienda el uso de electrodos de choque adhesivos para permitir su colocación adecuada. \\
\hline
\end{tabular}


Tabla 5. Recomendaciones de la American Heart Association para la reanimación cardiopulmonar de la embarazada, con su nivel y fuerza de recomendación ${ }^{6}$ (Continuación)

\begin{tabular}{|c|c|c|c|}
\hline Letra & Nivel* & Clase $^{\dagger}$ & Recomendación de RCP \\
\hline & C & Clase Ilb & $\begin{array}{l}\text { Para la taquicardia y la fibrilación ventriculares refractarias a la desfibrilación, se deberán } \\
\text { administrar rápidamente } 300 \mathrm{mg} \text { de amiodarona, seguida de dosis de } 150 \mathrm{mg} \text { si es preciso. }\end{array}$ \\
\hline & C & Clase I & $\begin{array}{l}\text { Durante la PCR, si la mujer gestante (en la que el útero se encuentra a nivel umbilical o por encima) } \\
\text { no ha recuperado la circulación espontánea con las maniobras de RCP y el desplazamiento del útero, } \\
\text { sería aconsejable prepararse para evacuar el útero mientras la RCP continúa. }\end{array}$ \\
\hline \multirow[t]{8}{*}{$\mathrm{E}$} & B & Clase I & Cuanto menor es el tiempo entre la PCR y la extracción, mejor es el resultado. \\
\hline & C & Clase Ila & $\begin{array}{l}\text { Se debe considerar seriamente realizar la cesárea perimortem en toda gestante que no haya } \\
\text { recuperado la circulación espontánea tras } 4 \text { minutos de reanimación. }\end{array}$ \\
\hline & C & Clase I & La valoración del estado fetal no deberá realizarse durante la reanimación. \\
\hline & B & Clase Ila & $\begin{array}{l}\text { La mujer no debe ser trasladada a un quirófano para la cesárea perimortem si la PCR se produce } \\
\text { en el contexto hospitalario. }\end{array}$ \\
\hline & C & Clase Ila & $\begin{array}{l}\text { No hay que esperar a disponer de equipo quirúrgico para comenzar con el procedimiento, solo se } \\
\text { necesita un bisturí. }\end{array}$ \\
\hline & C & Clase Ila & $\begin{array}{l}\text { El desplazamiento manual del útero debe realizarse durante toda la cesárea perimortem, hasta que } \\
\text { el feto es extraído. }\end{array}$ \\
\hline & C & Clase I & $\begin{array}{l}\text { Si la viabilidad materna no es posible (por lesión fatal o un tiempo de PCR prolongado), la } \\
\text { extracción deberá comenzar de inmediato, sin esperar para el inicio de la cesárea perimortem. }\end{array}$ \\
\hline & C & Clase Ilb & $\begin{array}{l}\text { El parto vaginal asistido debe ser considerado cuando la mujer se encuentra en dilatación } \\
\text { completa y la cabeza fetal está en una estación baja. }\end{array}$ \\
\hline \multirow[t]{5}{*}{ Generales } & C & Clase I & $\begin{array}{l}\text { Deberá existir un código para activar al equipo de PCR materna, que notifique a todos los } \\
\text { miembros y que permita que el material necesario sea llevado al lugar de la PCR sin retrasos. }\end{array}$ \\
\hline & C & Clase I & $\begin{array}{l}\text { Un mínimo de } 4 \text { miembros del equipo deben responder a la PCR materna e iniciar las maniobras de } \\
\text { SVB. Todo el personal del hospital debería ser capaz de adoptar todos los roles del equipo de } \\
\text { respuesta inicial. }\end{array}$ \\
\hline & C & Clase I & $\begin{array}{l}\text { El equipo de PCR materna debería estar compuesto, idealmente, por equipo de PCR adulto, equipo } \\
\text { de anestesia, equipo de neonatología y equipo de obstetricia. En centros que no disponen de } \\
\text { equipos obstétricos o de neonatología, se sugiere que el comité de PCR y los servicios de } \\
\text { urgencias del hospital establezcan planes en caso de PCR materno. }\end{array}$ \\
\hline & C & Clase I & $\begin{array}{l}\text { El establecimiento de un líder único durante la RCP materna es difícil debido a que se encuentran } \\
\text { implicados varios equipos. En general, deberá haber un líder de RCP del adulto, otro de obstetricia } \\
\text { y otro de neonatología. Una opción es que el líder habitual de la RCP delegue el liderazgo de la } \\
\text { atención obstétrica, de la atención de la vía aérea y de la atención del feto. Todos los líderes del } \\
\text { equipo deben comunicarse de forma efectiva para tomar decisiones. }\end{array}$ \\
\hline & C & Clase I & $\begin{array}{l}\text { La meta a futuro deberá ser disponer de programas nacionales e internacionales de formación en } \\
\text { RCP materna. }\end{array}$ \\
\hline \multirow[t]{5}{*}{$\begin{array}{l}\text { Post- } \\
\text { Paro }\end{array}$} & C & Clase I & $\begin{array}{l}\text { Si la paciente continúa embarazada, debe ser colocada en decúbito lateral izquierdo, siempre y } \\
\text { cuando no interfiera con otras }\end{array}$ \\
\hline & & & $\begin{array}{l}\text { necesidades como la monitorización de la paciente, el control de la vía aérea y el acceso } \\
\text { intravenoso. Si la paciente no se encuentra en decúbito lateral izquierdo, será necesario mantener } \\
\text { de forma continua el desplazamiento manual del útero. }\end{array}$ \\
\hline & C & Clase I & Tras la RCP la madre será trasladada a la unidad de cuidados intensivos \\
\hline & C & Clase I & El cuidado multidisciplinario debe continuar \\
\hline & C & Clase Ilb & El control de la temperatura debe considerarse de forma individual. \\
\hline
\end{tabular}

PCR: paro cardiorrespiratorio; RCP: reanimación cardiopulmonar; SVA: soporte vital avanzado; SVB: soporte vital básico.

*El nivel (calidad) de la evidencia se clasifica en: A) múltiples poblaciones evaluadas, datos derivados de múltiples ensayos clínicos o revisiones sistemáticas; B) poblaciones limitadas evaluadas, datos derivados de ensayos clínicos simples sin aleatorización; C) poblaciones muy limitadas evaluadas, datos derivados de consensos de opiniones de expertos y series de casos. Una recomendación de nivel C no significa que la recomendación sea débil; muchas preguntas clínicas abordadas en estas directrices no se prestan para ensayos clínicos.

${ }^{\dagger}$ La clase de recomendación se clasifica en: I) alta, el beneficio es ampliamente superior al riesgo y el procedimiento o tratamiento debe ser administrado; lla) moderada el beneficio es superior al riesgo, siendo razonable realizar el procedimiento tratamiento; llb) baja, el beneficio probablemente es superior 0 igual al riesgo, pero se requieren estudios adicionales, por lo que el tratamiento o procedimiento podría ser considerado; III) no hay beneficio y el procedimiento o tratamiento no debe ser realizado 0 administrado porque no es útil y puede ser perjudicial. 
manteniéndose el manejo multidisciplinario, el desplazamiento uterino y la necesidad de prepararse para una evacuación uterina inmediata si el PCR continúa ${ }^{28}$. Debido a que este es un hecho infrecuente en la embarazada, el nivel de evidencia de las recomendaciones es de baja calidad, basado en estudios limitados y opiniones de expertos. No obstante, la intensidad de estas recomendaciones es en su mayoría alta (clase I), traduciendo que el beneficio de realizarlas es superior al riesgo que podrían significar.

El algoritmo de la RCP materna se detalla a continuación y se esquematiza en la figura 2.

\section{Reconocimiento del paro cardiorrespiratorio y activación del código}

Ante una paciente inconsciente que no respira se debe activar el código de PCR, cuya denominación será variable según el centro (código azul, código rojo, código 911, etc.). Lo esencial en este punto es decir "código obstétrico", con el objetivo de que permita la movilización rápida de los distintos equipos antes señalados ${ }^{6}$. También permitirá la disposición del material necesario para llevar a cabo el SVA: implementos para manejo de vía aérea difícil, desfibrilador, equipo quirúrgico y tabla espinal. El equipo encargado de abordar la respuesta inicial del PCR debe iniciar de forma simultánea las maniobras de SVB.

\section{Compresiones torácicas en supino y tracción manual uterina}

Para realizar de forma correcta las compresiones se debe colocar a la paciente sobre una superficie dura en decúbito supino; no se recomienda el decúbito lateral izquierdo porque dificulta las compresiones torácicas. Así, la AHA recomienda el desplazamiento manual uterino a la izquierda ${ }^{6}$, para lo cual existen dos técnicas: con una o con dos manos (Fig. 3). La técnica preferida es la bimanual, desde el lado izquierdo de la paciente, tirando hacia arriba y hacia la izquierda el útero, con un equivalente a un desplazamiento uterino de $30^{\circ}$.

Debido a la elevación del diafragma por el útero grávido, algunas recomendaciones previas instaban a colocar las manos en una posición ligeramente superior a la estándar ${ }^{29}$. Sin embargo, no existe evidencia acerca del beneficio de dicha recomendación y, por tanto, no se debe modificar la posición de las manos, manteniéndolas en el centro del pecho, igual que en la mujer no embarazada ${ }^{30}$.

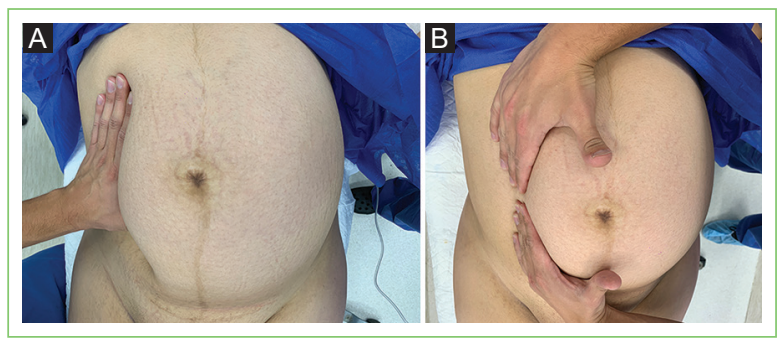

Figura 3. Desplazamiento manual uterino a la izquierda. A: técnica con una mano desde la derecha de la paciente. B: técnica con dos manos desde la izquierda de la paciente.

\section{Vía aérea y ventilación}

Para proceder a la apertura de la vía aérea pueden emplearse la maniobra frente-mentón o la maniobra de tracción mandibular. Dado que la gestante en apnea desatura mucho más rápido que la no embarazada, serán necesarias intervenciones diligentes, efectivas y de calidad. El equipo encargado del SVB deberá ventilar a la paciente con una bolsa autoinflable y oxígeno al 100\% administrando 15 litros por minuto. Si no se cuenta con un anestesiólogo se recomienda seguir ventilando con mascarilla hasta la recuperación de la circulación, en vez de intentar intubar la tráquea ${ }^{6}$.

El manejo avanzado de la vía aérea debe realizarse de forma precoz por un anestesiólogo o un experto, y se detalla en la figura 2. No se recomienda realizar más de dos intentos de laringoscopia, ya que estos se asocian a resultados adversos (aspiración de contenido gástrico, lesiones y sangrado de la vía aérea) y aumentan la dificultad en laringoscopias subsecuentes ${ }^{31}$. Así, se debe tener un bajo umbral para instalar un dispositivo supraglótico (máscara laríngea o similar) como plan alternativo, siendo la técnica de elección ante la intubación traqueal fallida. Según el reporte de $4^{\text {th }}$ National Audit Proyect, en el escenario obstétrico hubo cuatro casos de intubación traqueal fallida con estadía posterior en la unidad de cuidados intensivos, donde en tres de las pacientes se logró superar la situación con una máscara laríngea ${ }^{32}$.

En el proceso de intubación traqueal en la embarazada se ha utilizado tradicionalmente la compresión cricoidea (maniobra de Sellick) para disminuir el riesgo teórico de aspiración de contenido gástrico. Sin embargo, esto no ha sido validado en los reportes y, más importante aún, esta maniobra empeora la visualización de las cuerdas vocales en una paciente con alta incidencia de vía aérea difícil en la que se 
requiere con premura un acceso rápido, por lo que no se recomienda en el escenario de PCR en la embarazada ${ }^{6}$.

Si está disponible, será útil el uso de capnografía continua, ya que permitirá valorar la confirmación de la correcta ubicación del tubo traqueal y la recuperación de la circulación espontánea con valores sobre $10 \mathrm{mmHg}$ de dióxido de carbono espirado.

\section{Desfibrilación}

Tan pronto como el desfibrilador esté disponible se deberá colocar, siendo recomendable su uso en los primeros 3 minutos del PCR si la paciente presenta un ritmo desfibrilable (fibrilación ventricular o taquicardia ventricular sin pulso).

Lo ideal es utilizar un desfibrilador externo automático debido a que en el ámbito obstétrico no hay mucho entrenamiento ni familiaridad con los ritmos desfibrilables y no desfibrilables (asistolia o actividad eléctrica sin pulso). En cuanto a la energía a utilizar, no difiere de la que se aplica a las no embarazadas y debería ser de 120-200 J con los desfibriladores bifásicos $^{6}$. El resto de las recomendaciones se detallan en la tabla 5, letra D.

\section{Fármacos}

Aunque algunos fármacos, como la epinefrina y la vasopresina, disminuyen el flujo sanguíneo placentario, está indicado su uso. No debe evitarse ningún medicamento alegando eventuales problemas de perfusión útero-placentaria, ya que la vida de la madre es la prioridad en esta situación.

\section{Extracción fetal: parto por la vía más expedita}

Constituye el mayor cambio respecto a la reanimación de una paciente no embarazada. Si tras 4 minutos de RCP la gestante no tiene pulso, será necesario realizar la extracción fetal por la vía más expedita ${ }^{33}$. Cuanto la gestante se encuentra con dilatación completa y la cabeza fetal está en una posición adecuada, se puede considerar la realización de un parto vaginal, siempre que se lleven a cabo las maniobras de RCP apropiadamente. Sin embargo, generalmente esto no es posible, por lo que la histerotomía de emergencia es la opción más rápida.

\section{Cesárea perimortem. ¿Qué debemos considerar?}

La cesárea perimortem es la histerotomía por la que se produce el nacimiento del feto luego de un PCR materno, en general durante la reanimación. Es un procedimiento infrecuente, que permite aumentar las probabilidades de sobrevida tanto materna como fetal.

En la actualidad, su realización en el PCR materno está en aumento, desde el $22 \%$ en 2010 hasta el $74 \%$ en $2017^{12,15}$. Sin embargo, aún se producen retrasos en llevarla a cabo, probablemente por la creencia errónea de que solo beneficia al feto, el miedo a las implicancias médico-legales y la desconfianza de hacerla en un ambiente no estéril lejos del quirófano.

\section{¿Por qué permite aumentar la solbrevida materna?}

La evacuación uterina permite la descompresión de la vena cava inferior, reduce la proporción del gasto cardiaco destinado a la perfusión uterina, aumenta el gasto cardiaco materno un $60 \%$ y restablece el desplazamiento diafragmático ${ }^{30}$.

La sobrevida materna tras una cesárea perimortem varía entre el 34 y el $54 \%{ }^{34,35}$. En una serie de 38 cesáreas perimortem no se reportaron casos de empeoramiento del estado materno tras su realización, y 12 de 20 madres (60\%) tuvieron retorno de la circulación espontánea inmediatamente tras la cesárea ${ }^{36}$. Debido a que el daño cerebral hipóxico en la embarazada ocurre con mayor rapidez que en una paciente no embarazada ${ }^{12}$, Einav, et al. ${ }^{34}$ valoraron el deterioro neurológico de las madres tras un PCR y una cesárea perimortem utilizando la escala Cerebral Performance Categories, y el $80 \%$ de las madres tuvieron una buena recuperación neurológica.

\section{¿Por qué permite aumentar la sobrevida fetal?}

La sobrevida fetal tras una cesárea perimortem es muy variable, entre el $5 \%$ y el $89 \%{ }^{35,37}$. Cuanto antes se realice, mejor es el desenlace fetal; en un estudio, el tiempo medio desde el PCR hasta el nacimiento fue de $14 \pm 11$ minutos en los neonatos sobrevivientes, mientras que fue de $22 \pm 13$ minutos en los que no lograron sobrevivir $(p=0,016)^{38}$. 


\section{¿Su indicación depende de las semanas de gestación?}

No toda mujer en PCR es candidata a cesárea perimortem; la decisión depende de si el útero grávido interfiere con la hemodinamia materna. De hecho, las recomendaciones del Consejo Europeo de Resucitación señalan que cuando la edad gestacional es inferior a 20 semanas la cesárea perimortem no está indicada, pues el tamaño uterino no produce un compromiso significativo del retorno venoso y del gasto cardiaco, siendo la reanimación muy similar a la de la mujer no embarazada ${ }^{29}$.

Actualmente, 24 semanas de edad gestacional se considera el umbral de viabilidad fetal, con un rango aceptable entre 23 y 25 semanas $^{39,40}$. Así, las guías recomiendan la cesárea ante un PCR en embarazos de más de 24 semanas para aumentar la sobrevida del binomio materno-fetal. En las mujeres con PCR y embarazos no viables y de más de 20 semanas, si el PCR continúa también debe ser una opción la cesárea perimortem para aumentar la sobrevida materna ${ }^{6}$. Si se desconoce la edad gestacional de la madre en PCR es útil la palpación del útero sobre el ombligo, situación acorde aproximadamente a 20 semanas de gestación. Si está sobre el ombligo, puede ser necesario una cesárea perimortem para lograr el retorno de la circulación espontánea.

\section{¿En cuánto tiempo se debe iniciar?}

Se establece que el feto debe ser extraído a los 5 minutos del PCR, iniciando la incisión a los 4 minutos del inicio del PCR, lo que permitiría disminuir los daños neurológicos maternos y fetales, que se desarrollarían luego de 4-6 minutos si no hay retorno de la circulación espontánea ${ }^{41}$.

\section{¿Dónde se debe realizar la cirugía?}

Se debe realizar en el mismo lugar del PCR materno, evitando el traslado a un quirófano, ya que este interfiere con la reanimación, disminuye la eficacia de las compresiones torácicas y retrasa la extracción fetal ${ }^{42}$. Idealmente debería contarse con guantes estériles, mascarilla con protección ocular, delantal estéril, solución desinfectante, valva suprapúbica, retractores, pinza de disección, dos pinzas Kocher, suturas, portaagujas, tijeras y compresas, pero para su ejecución

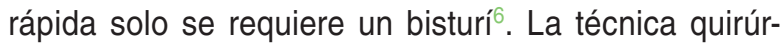
gica dependerá del juicio del obstetra que la realice, que se recomienda que sea el obstetra con más experiencia presente ${ }^{43}$. Cuando lo más importante es la velocidad del procedimiento, se recomienda el abordaje clásico por la línea media debido a que es más rápido y con menos estructuras que cortar, dada la diástasis natural de los rectos abdominales que ocurre durante el embarazo. Así, se logran tiempos quirúrgicos inferiores que con la incisión de Pfannenstiel ${ }^{44}$. Además, permite una buena visualización, un mínimo daño a la vejiga y la posibilidad de comprimir o realizar una histerectomía para el control de una hemorragia. El cierre adicional, una vez nacido el feto, debe hacerse en el quirófano.

\section{¿Y si el paro cardiorrespiratorio fue extrahospitalario? ¿Dónde derivar? ¿Cuándo hacer la cesárea perimortem?}

EI PCR materno extrahospitalario se asocia a mayor mortalidad que el PCR materno intrahospitalario ${ }^{12,45}$. El traslado de la madre en PCR debe ser a un centro preparado para la ejecución de una cesárea perimortem y no al centro más cercano donde esta no se podrá ejecutar.

En este caso, la cesárea perimortem debería hacerse inmediatamente al llegar al hospital, ya que se han reportado desenlaces neurológicos favorables fetales y maternos incluso tras 45-60 minutos desde el PCR ${ }^{42,46}$.

\section{Identificación y tratamiento de la causa del paro cardiorrespiratorio}

El conocimiento de la causa del PCR condiciona su tratamiento. Ante una hemorragia, se deberá contar con vías gruesas, reanimación precoz con volumen y uterotónicos si la causa es por hipotonía uterina, que es lo más frecuente en la metrorragia posparto. La intervención inicial debe contemplar transfusión de hemoderivados, evacuación de restos ovulares del útero y, si procede, compresión mecánica del útero. También pueden ser útiles la ligadura y la embolización vascular, o una histerectomía. Cuando se desconoce el origen del sangrado es necesario explorar el hígado, el bazo y el espacio retroperitoneal.

La implementación de tromboprofilaxis sistemática ha disminuido la incidencia de las causas embólicas. Sin embargo, en la embolia amniótica el tratamiento es de soporte, buscando corregir la coagulopatía, la hemorragia y la hipertensión pulmonar. Se ha visto que la circulación extracorpórea de urgencia y la oxigenación por membrana extracorpórea (ECMO) pueden resultar 
exitosas para el tratamiento, considerando también la administración de prostaciclinas o de óxido nítrico inhalado para tratar la hipertensión pulmonar . $^{6}$

Ante causas anestésicas, se deberán administrar antídotos como cloruro de calcio (en caso de intoxicación por magnesio), naloxona (en caso de depresión respiratoria) o infusión lipídica (en caso de intoxicación por anestésicos locales).

Respecto a las causas cardiovasculares, el cateterismo cardiaco se prefiere a la trombólisis.

Finalmente, si la causa es hipertensiva la mejor estrategia preventiva de la eclampsia es el sulfato de magnesio.

Se recomienda que tras la recuperación de la circulación espontánea se realice una evaluación neurorradiológica para diagnosticar problemas intracraneales y determinar el pronóstico.

\section{Cuidados tras el paro cardiorrespiratorio}

Una vez recuperada la circulación espontánea se debe colocar a la paciente en decúbito lateral izquierdo o mantener el desplazamiento manual uterino. Si ya se efectuó la cesárea perimortem, este no será necesario. Se recomienda que la paciente sea trasladada a una unidad de tratamiento intensivo, donde la causa del PCR debe continuar siendo tratada ${ }^{6}$. Se debe optimizar la perfusión a los órganos, principalmente al cerebro. Existen dos reportes de casos en los que se instauró una hipotermia moderada $\left(32-34{ }^{\circ} \mathrm{C}\right)$ tras la reanimación a la madre, logrando desenlaces neurológicos favorables ${ }^{47,48}$.

\section{Uso de listas de verificación}

El uso de listas de verificación y ayudas cognitivas puede ayudar a recordar a los reanimadores información importante durante periodos de estrés intenso. Un estudio demostró que las acciones críticas vitales realizadas por un equipo de simulación obstétrico fueron correctas cuando una ayuda cognitiva verbal asistía al líder de la reanimación ${ }^{49}$. La lista de verificación para PCR obstétrico se describe en la tabla 6, y también puede ser una herramienta de autoevaluación después del evento 0 en un escenario de simulación.

\section{Reanimación cardiopulmonar durante la pandemia de COVID-19}

Debido que la RCP es un procedimiento de alto riesgo de generación de aerosoles, antes de entrar a
Tabla 6. Lista de verificación para reanimación cardiopulmonar materna ${ }^{6}$

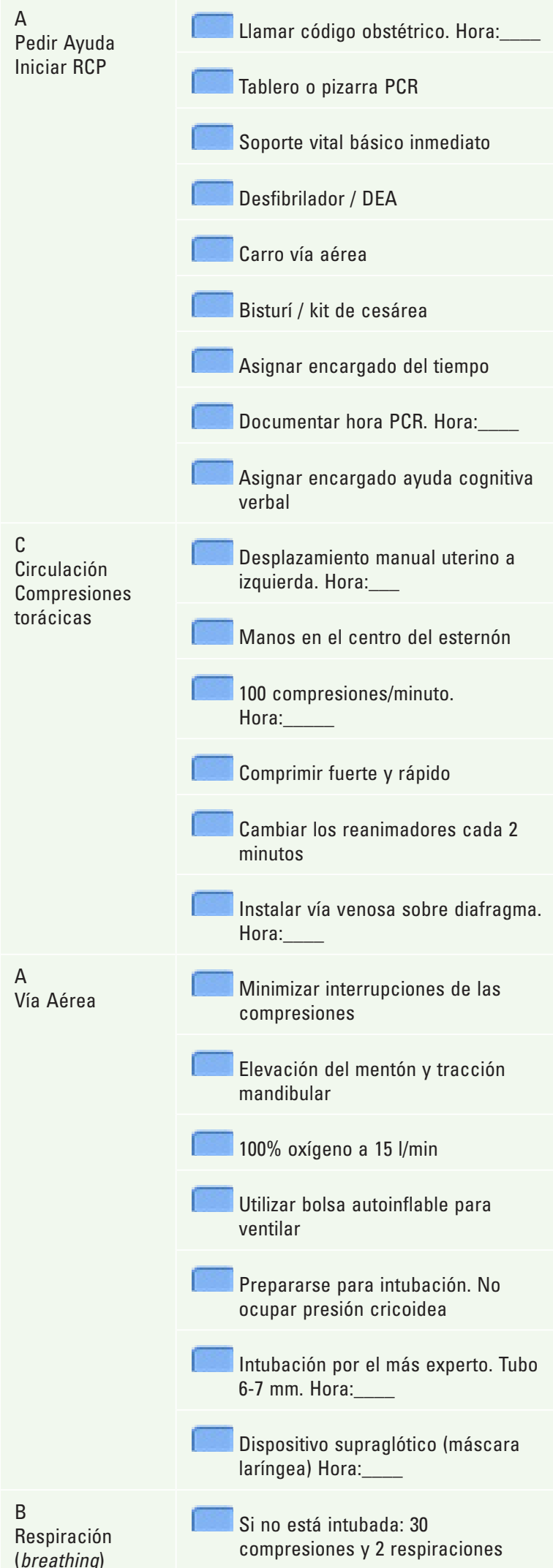


Tabla 6. Lista de verificación para reanimación cardiopulmonar materna ${ }^{6}$ (Continuación)

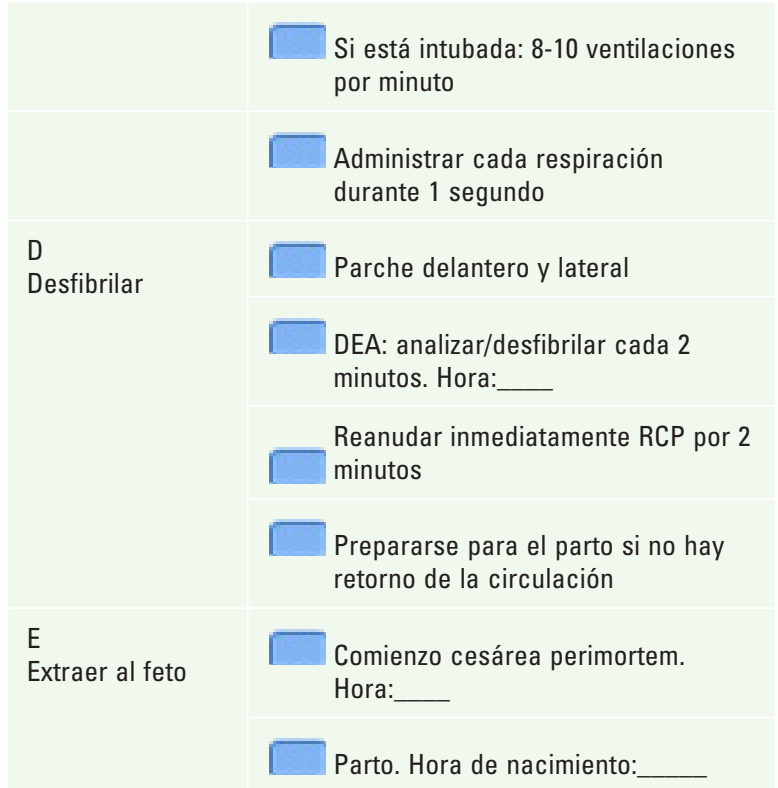

DEA: desfibrilador externo automático.

la escena todos los reanimadores deben usar elementos de protección personal. También se debe limitar el número de personas en la RCP, conectar un filtro de alta eficacia de partículas de aire y preferir el uso de videolaringoscopi ${ }^{50}$.

\section{Conclusiones}

Para enfrentarse correctamente a un PCR en la embarazada será necesaria la coordinación de varios equipos de forma simultánea: obstetricia, anestesia, equipo de PCR adulto y neonatología.

Las acciones distintivas de una RCP materna son la activación del código de urgencia obstétrico, la desviación manual uterina a la izquierda, la reanimación avanzada por un anestesiólogo y la eventual realización de una cesárea perimortem en el mismo sitio, sin traslado a un quirófano.

\section{Financiamiento}

El presente artículo contó exclusivamente con el financiamiento Institucional y Divisional.

\section{Conflicto de intereses}

Los autores no poseen conflictos de intereses.

\section{Responsabilidades éticas}

Protección de personas y animales. Los autores declaran que para esta investigación no se han realizado experimentos en seres humanos ni en animales.

Confidencialidad de los datos. Los autores declaran que han seguido los protocolos de su centro de trabajo sobre la publicación de datos de pacientes.

Derecho a la privacidad y consentimiento informado. Los autores han obtenido el consentimiento informado de los pacientes y/o sujetos referidos en el artículo. Este documento obra en poder del autor de correspondencia.

\section{Bibliografía}

1. Mhyre JM, Tsen LC, Einav S, Kuklina EV, Leffert LR, Bateman BT. Cardiac arrest during hospitalization for delivery in the United States, 1998-2011. Anesthesiology. 2014;120:810-8.

2. Morris S, Stacey M. Resuscitation in pregnancy. BMJ. 2003;327:1277-9.

3. Balki M, Liu S, León JA, Baghirzada L. Epidemiology of cardiac arrest during hospitalization for delivery in Canada: a nationwide study. Anesth Analg. 2017;124:890-7.

4. González-Sáenz M, Soto-Cerdas J. Mortalidad materna: análisis médico forense. Med Leg Costa Rica. 2017;34:112-9. [citado 5 Oct 2020]. Disponible en: http://www.scielo.sa.cr/scielo.php?script=sci_arttext\&pi$\mathrm{d}=$ S1409-00152017000100112\&Ing=en.

5. Say L, Chou D, Gemmill A, Tunçalp O, Moller A, Daniels J, et al. Global causes of maternal death: a WHO systematic analysis. Lancet Glob Health. 2014;2:e323-33.

6. Jeejeebhoy FM, Zelop CM, Lipman S, Carvalho B, Joglar J, Mhyre JM, et al. Cardiac arrest in pregnancy: a scientific statement from the American Heart Association. Circulation. 2015;132:1747-73.

7. WHO, UNICEF, UNFPA, World Bank Group and the United Nations Population Division for the years 2000-2017. Trends in estimates of maternal mortality ratio, maternal deaths and lifetime risk of maternal death. 2019. Disponible en: https://www.who.int/gho/mdg/maternal_health/countries/en

8. Vera CM, Donoso E. Desaceleración en la reducción de la mortalidad materna en Chile impide alcanzar el $5 .^{\circ}$ Objetivo de Desarrollo del Milenio. ARS Med. 2019;44:13-20. [citado 25 Oct 2020]. Disponible en: https://arsmedica.cl/index.php/MED/article/view/1526

9. Donoso E, Carvajal J. El cambio del perfil epidemiológico de la mortalidad materna en Chile dificultará el cumplimiento del 5. objetivo del Milenio. Rev Med Chile. 2012;140:1253-62. [citado 12 Oct 2020]. Disponible en: https://scielo.conicyt.cl/scielo.php?script=sci_arttext\&pi$d=S 003498872012001000003 \&$ Ing=es.

10. Rangel-Flores $Y$, Martínez-Ledesma A. La investigación en morbilidad materna extrema "near miss" en América Latina. Rev Peru Med Exp Salud Publica. 2017;34:505-11. [citado 8 Nov 2020]. Disponible en: http:// www.scielo.org.pe/scielo.php?script=sci_arttext\&pi$\mathrm{d}=$ S172646342017000300018\&lng=es.

11. Naciones Unidas. Objetivos de Desarrollo Sostenible: Agenda 2030. Objetivo 3: Garantizar una vida sana y promover el bienestar para todos en todas las edades. 2016. [citado 22 Oct 2020]. Disponible en: http:// www.un.org/sustainabledevelopment/es/health/.

12. Beckett VA, Knight M, Sharpe P. The CAPS Study: incidence, management and outcomes of cardiac arrest in pregnancy in the UK: a prospective, descriptive study. BJOG. 2017;124:1374-81.

13. Rossi A, Cornette J, Johnson MR, Karamermer Y, Springeling T, Opic P, et al. Quantitative cardiovascular magnetic resonance in pregnant women: cross-sectional analysis of physiological parameters throughout pregnancy and the impact of the supine position. J Cardiovasc Magn Reson. 2011;13:31.

14. Lavecchia M, Abenhaim HA. Cardiopulmonary resuscitation of pregnant women in the emergency department. Resuscitation. 2015;91:104-7.

15. Dijkman A, Huisman C, Smit M, Schutte JM, Zwart J, Van Roosmalen, et al. Cardiac arrest in pregnancy: increased use of perimortem caesarean section due to emergency skills training? BJOG. 2010;117:282-7.

16. Vanden Hoek T, Morrison LJ, Shuster M, Donnino M, Sinzet E, Lavonas E, et al. Part 12: Cardiac arrest in special situations. Circulation. 2010;122:S829-61. 
17. Vasco-Ramírez M. Resucitación cardiopulmonar y cerebral en la embarazada. Al final del colapso materno. Rev Colomb Obstet Ginecol. 2014;65:228-42. [citado 23 Oct 2020]. Disponible en: https://revista.fecolsog.org/index.php/rcog/article/view/50

18. Chan P, Berg R, Spertus JA, Schwamm LH, Bhatt DL, Fonarow A, et al Risk-standardizing survival for in-hospital cardiac arrest to facilitate hospital comparisons. J Am Coll Cardiol. 2013;62:601-9.

19. Madrigal S, Eduardo M, Morera V, Adrián C. Paro cardíaco en el embarazo. Rev Costarric Cardiol. 2013;15:35-43. [citado 12 Sept 2020]. Dis ponible en: http://www.scielo.sa.cr/scielo.php?script=sci_arttext\&pi$\mathrm{d}=\mathrm{S} 1409-41422013000200006 \& \operatorname{lng}=\mathrm{en}$.

20. Jauniaux E, Ayres-de-Campos D, Langhoff-Roos J, Fox KA, Collins S, Duncombe G, et al. FIGO classification for the clinical diagnosis of placenta accreta spectrum disorders. Int J Gynecol Obstet. 2019;146:20-4

21. James $A H$, Jamison MG, Biswas MS, Brancazio LR, Swamy GK, Myers ER. Acute myocardial infarction in pregnancy: a United States population-based study. Circulation. 2006;113:1564-71.

22. Abe K, Kuklina EV, Hooper WC, Callaghan WM. Venous thromboembolism as a cause of severe maternal morbidity and mortality in the United States. Semin Perinatol. 2019;43:200-4.

23. Meza FE, Betancourt M, Moncada E, Flores V, Vázquez JC. Cesárea perimortem por trauma penetrante por proyectil de arma de fuego con supervivencia fetal. Reporte de un caso. Rev Fac Med (Mex). 2018;61:24-8. [citado 12 Sept 2020]. Disponible en: http://www.scielo. org. $\mathrm{mx} / \mathrm{scielo}$. php ? script $=\mathrm{sci}$ arttext\& pi $\mathrm{d}=$ S0026-17422018000200024\&Ing=es.

24. Kilpatrick SJ. Trauma in pregnancy: an underappreciated cause of maternal death Am J Obstet Gynecol. 2017;217:499-500.

25. Bakhbakhi D, Gamaleldin I, Siassakos D. Cardiopulmonary resuscitation of pregnant women. Resuscitation. 2015;91:A5-6.

26. Hillman SL, Cooper NC, Siassakos D. Born to survive: a critical review of out-of-hospital maternal cardiac arrests and pre-hospital perimortem caesarean section. Resuscitation. 2019;135:224-5

27. Montufar-Rueda C, Gei A. Cardiac arrest during pregnancy. Clin Obste Gynecol. 2014;57:871-81.

28. Nolan J, Maconochie I, Soar J, Olasveengen T, Greif R, Wyckoff M, et al Executive Summary: 2020 International Consensus on Cardiopulmonary Resuscitation and Emergency Cardiovascular Care Science With Treatment Recommendations. Circulation. 2020;142:S2-27.

29. Monsieurs KG, Nolan JP, Bossaert LL, Greif R, Maconochie IK, Nikolaou NI, et al. European Resuscitation Council Guidelines for Resuscitation 2015. Resuscitation. 2015;95:1-80.

30. Healy ME, Kozubal DE, Horn AE, Vilke GM, Chan TC, Ufberg JW. Care of the critically ill pregnant patient and perimortem cesarean delivery in the emergency department. J Emerg Med. 2016;51:172-7.

31. Guzman J. Vía aérea difícil en anestesia obstétrica. Rev Chil Anest. 2010;39:116-24.

32. Keller C, Brimacombe J, Lirk P, Puhringer F. Failed obstetric trachea intubation and postoperative respiratory support with the ProSeal laryngeal mask airway. Anesth Analg. 2004:98:1467-70.

33. Rose CH, Faksh A, Traynor KD, Cabrera D, Arendt KW, Brost BC. Challenging the 4- to 5-minute rule: from perimortem cesarean to resuscitative hysterotomy. Am J Obstet Gynecol. 2015;213:653-6.
34. Einav S, Kaufman N, Sela HY. Maternal cardiac arrest and perimortem caesarean delivery: evidence or expert-based? Resuscitation. 2012;83:1191-200.

35. Drukker L, Hants Y, Sharon E, Sela HY, Grisaru-Granovsky S. Perimortem cesarean section for maternal and fetal salvage: concise review and protocol. Acta Obstet Gynecol Scand. 2014;93:965-72.

36. Katz V, Balderston K, DeFreest M. Perimortem cesarean delivery: were our assumptions correct? Am J Obstet Gynecol. 2005;192:1916-21.

37. Whitty JE. Maternal cardiac arrest in pregnancy. Clin Obstet Gynecol. 2002;45:377-92

38. Fischer C, Bonnet MP, Girault A, Le Ray C. Update: Focus in-hospital maternal cardiac arrest. J Gynecol Obstet Hum Reprod. 2019;48:309-14.

39. Phibbs CS, Baker LC, Caughey AB, Danielsen B, Schmitt SK, Phibbs RH. Level and volume of neonatal intensive care and mortality in very-low-birthweight infants. N Engl J Med. 2007;356:2165-75.

40. Gillam L, Wilkinson D, Xafis V, Isaacs D. Decision-making at the borderline of viability: who should decide and on what basis? J Paediatr Child Health. 2017;53:105-11.

41. Benson MD, Padovano A, Bourjeily G, Zhou Y. Maternal collapse: challenging the four-minute rule. EbioMedicine. 2016;6:253-7.

42. Lipman S, Cohen S, Einav S, Jeejeebhoy F, Mhyre JM, Morrison LJ, et al. The Society for Obstetric Anesthesia and Perinatology consensus statement on the management of cardiac arrest in pregnancy. Anesth Analg. 2014;118:1003-16.

43. Alexander AM, Sheraton M, Lobrano S. Perimortem cesarean delivery. StatPearls; 2019. [citado 13 Sept 2020]. Disponible en: https://www.ncbi. nlm.nih.gov/books/NBK534240

44. Moors X, Biesheuvel TH, Cornette J, Van Vledder MG, Veen A, Quelerij M, et al, Analysis of prehospital perimortem caesarean deliveries performed by helicopter emergency medical services in the Netherlands and recommendations for the future. Resuscitation. 2020;155: $112-8$.

45. Maurin O, Lemoine S, Jost D, Lanoë V, Renard A, Travers S, et al Maternal out-of-hospital cardiac arrest: a retrospective observational study. Resuscitation. 2019;135:205-11.

46. Kazandi M, Mgoyi L Post-mortem caesarean section performed $30 \mathrm{minu}$ tes after maternal cardiopulmonary arrest. Austr NZ Obstetric-Gynaecol. 2004; $44: 351-3$

47. Chauhan A, Musunuru H, Donnino M, McCurdy MT, Chauhan V, Walsh M. The use of therapeutic hypothermia after cardiac arrest in a pregnant patient. Ann Emerg Med. 2012;60:786-9.

48. Rittenberger JC, Kelly E, Jang D, Greer K, Heffner A. Successful outcome utilizing hypothermia after cardiac arrest in pregnancy: a case report. Crit Care Med. 2008;36:1354-6.

49. Burden AR, Carr ZJ, Staman GW, Littman JJ, Torjman MC. Does every code need a "reader?" Improvement of rare event management with a cognitive aid "reader" during a simulated emergency: a pilot study. Simul Healthc. 2012;7:1-9.

50. Edelson DP, Sasson C, Chan PS, Atkins DL, Aziz K, Becker LB, et al. Interim guidance for basic and advanced life support in adults, children, and neonates with suspected or confirmed COVID-19: from the Emergency Cardiovascular Care Committee and get with the Guidelines-Resuscitation Adult and Pediatric Task Forces of the American Heart Association. Circulation. 2020;141:e933-43. 